NASA/TM-2006-214420

ARL-MR-0643
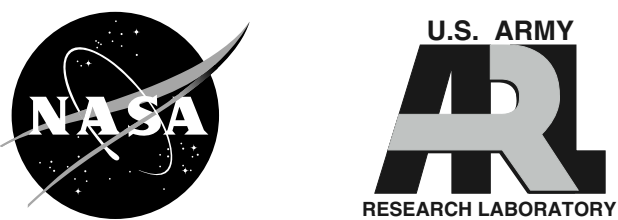

AIAA-2006-4754

\title{
Continued Investigation of Leakage and Power Loss Test Results for Competing Turbine Engine Seals
}

Irebert R. Delgado

U.S. Army Research Laboratory, Glenn Research Center, Cleveland, Ohio

Margaret P. Proctor

Glenn Research Center, Cleveland, Ohio 


\section{NASA STI Program . . . in Profile}

Since its founding, NASA has been dedicated to the advancement of aeronautics and space science. The NASA Scientific and Technical Information (STI) program plays a key part in helping NASA maintain this important role.

The NASA STI Program operates under the auspices of the Agency Chief Information Officer. It collects, organizes, provides for archiving, and disseminates NASA's STI. The NASA STI program provides access to the NASA Aeronautics and Space Database and its public interface, the NASA Technical Reports Server, thus providing one of the largest collections of aeronautical and space science STI in the world. Results are published in both non-NASA channels and by NASA in the NASA STI Report Series, which includes the following report types:

- TECHNICAL PUBLICATION. Reports of completed research or a major significant phase of research that present the results of NASA programs and include extensive data or theoretical analysis. Includes compilations of significant scientific and technical data and information deemed to be of continuing reference value. NASA counterpart of peer-reviewed formal professional papers but has less stringent limitations on manuscript length and extent of graphic presentations.

- TECHNICAL MEMORANDUM. Scientific and technical findings that are preliminary or of specialized interest, e.g., quick release reports, working papers, and bibliographies that contain minimal annotation. Does not contain extensive analysis.

- CONTRACTOR REPORT. Scientific and technical findings by NASA-sponsored contractors and grantees.
- CONFERENCE PUBLICATION. Collected papers from scientific and technical conferences, symposia, seminars, or other meetings sponsored or cosponsored by NASA.

- SPECIAL PUBLICATION. Scientific, technical, or historical information from NASA programs, projects, and missions, often concerned with subjects having substantial public interest.

- TECHNICAL TRANSLATION. Englishlanguage translations of foreign scientific and technical material pertinent to NASA's mission.

Specialized services also include creating custom thesauri, building customized databases, organizing and publishing research results.

For more information about the NASA STI program, see the following:

- Access the NASA STI program home page at http://www.sti.nasa.gov

- E-mail your question via the Internet to help@sti.nasa.gov

- Fax your question to the NASA STI Help Desk at 301-621-0134

- Telephone the NASA STI Help Desk at 301-621-0390

- Write to:

NASA STI Help Desk

NASA Center for AeroSpace Information 7121 Standard Drive Hanover, MD 21076-1320 
NASA/TM-2006-214420

ARL-MR-0643
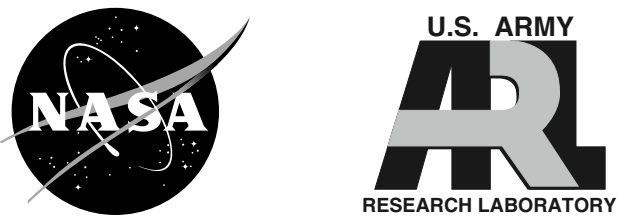

AIAA-2006-4754

\section{Continued Investigation of Leakage and Power Loss Test Results for Competing Turbine Engine Seals}

Irebert R. Delgado

U.S. Army Research Laboratory, Glenn Research Center, Cleveland, Ohio

Margaret P. Proctor

Glenn Research Center, Cleveland, Ohio

Prepared for the

42nd Joint Propulsion Conference and Exhibit cosponsored by the AIAA, ASME, SAE, and ASEE

Sacramento, California, July 9-12, 2006

National Aeronautics and

Space Administration

Glenn Research Center

Cleveland, Ohio 44135 
Trade names and trademarks are used in this report for identification only. Their usage does not constitute an official endorsement, either expressed or implied, by the National Aeronautics and Space Administration.

This work was sponsored by the Fundamental Aeronautics Program at the NASA Glenn Research Center.

Level of Review: This material has been technically reviewed by technical management.

Available from

NASA Center for Aerospace Information 7121 Standard Drive

Hanover, MD 21076-1320
National Technical Information Service 5285 Port Royal Road Springfield, VA 22161 


\title{
Continued Investigation of Leakage and Power Loss Test Results for Competing Turbine Engine Seals
}

\author{
Irebert R. Delgado \\ U.S. Army Research Laboratory \\ Glenn Research Center \\ Cleveland, Ohio 44135 \\ Margaret P. Proctor \\ National Aeronautics and Space Administration \\ Glenn Research Center \\ Cleveland, Ohio 44135
}

\begin{abstract}
Secondary seal leakage in jet engine applications results in power losses to the engine cycle. Likewise, seal power loss in jet engines not only result in efficiency loss but also increase the heat input into the engine resulting in reduced component lives. Experimental work on labyrinth and annular seals was performed at NASA's Glenn Research Center to quantify seal leakage and power loss at various temperatures, seal pressure differentials, and surface speeds. Data from annular and labyrinth seals are compared with previous brush and finger seal test results. Data are also compared to literature. Annular and labyrinth seal leakage rates are 2 to 3 times greater than brush and finger seal rates. Seal leakage decreases with increasing speed but increases with increasing test temperature due to thermal expansion mismatch. Also seal power loss increases with surface speed, seal pressure differential, mass flow rate, and radial clearance. Annular and labyrinth seal power losses were higher than those of brush or finger seal data. The brush seal power loss was 15 to 30 percent lower than annular and labyrinth seal power loss.
\end{abstract}

\section{Nomenclature}

$C_{\text {eff }} \quad$ effective clearance, microns

$C_{m, o} \quad$ torque coefficient for case of no through flow

$D_{\text {seal }} \quad$ outside diameter of test disk, m

$D_{1} \quad$ bearing bore diameter, $\mathrm{m}$

$M_{o} \quad$ torque on one side of a disk, N-m

$P_{u} \quad$ air pressure upstream of seal, $\mathrm{MPa}$

$R \quad$ gas constant $=287 \mathrm{~J} / \mathrm{kg}-\mathrm{K}$ for air

Re Reynolds number $=\omega \mathrm{a}^{2} \rho / \mu$

$T$ torque, $\mathrm{N}-\mathrm{m}$

$T_{\text {avg }} \quad$ average seal air inlet temperature, $\mathrm{K}$

$W \quad$ load on bearing, $\mathrm{N}$

$a$ disk radius, $\mathrm{m}$

$f$ friction coefficient

$g \quad$ conversion constant $=1$

$g_{c} \quad$ conversion factor $=1$ for SI units

$s \quad$ axial clearance between disk and housing, $\mathrm{m}$

$\dot{m} \quad$ air leakage flow rate, $\mathrm{kg} / \mathrm{s}$

$\phi \quad$ flow factor, $\mathrm{kg}-\sqrt{\mathrm{K}} / \mathrm{MPa}-\mathrm{m}-\mathrm{s}$

$\gamma \quad$ ratio of specific heats $=1.4$ for air

$\mu \quad$ dynamic viscosity, $\mathrm{N}-\mathrm{s} / \mathrm{m}^{2}$

$\rho$ density of fluid, $\mathrm{kg} / \mathrm{m}^{3}$

$\omega \quad$ angular velocity, $\mathrm{rad} / \mathrm{s}$ 


\section{Introduction}

Maintaining jet engine efficiency is vital to extracting as much power out of the engine as possible. Unwanted disk windage, or "viscous drag on rotating components" in the secondary air flow system results in additional heat input into the secondary cooling system which reduces the fatigue life of downstream engine components (ref. 1). Disk windage in a jet engine may be defined as any rotating or stationary component that generates local air heating due to viscous drag of the air.

Engine seals provide a means to control parasitic air leakage into the secondary flow path, separate air and oil cavities, prevent hot gas ingestion into the turbine/stator cavities, and prevent air leakage around compressor and turbine blades. However, engine seals may also cause unwanted heat input into the flow path. This power loss due to the seal may be in the form of heat input into the air stream due to viscous drag or friction from the seal. Examples of frictional heating include labyrinth or brush seal rubs on abradable coatings.

Current and advanced engine seals (i.e., labyrinth, brush, finger, and non-contacting seals) are tested at NASA's Glenn Research Center turbine seal rig at unique temperature, pressure, and surface speed combinations. In addition to measuring seal leakage, the seal rig can measure seal torque by means of a torquemeter installed between the air turbine and the main shaft. This capability enables seal power loss calculations.

Recent seal leakage and power loss test results obtained in the NASA turbine seal rig by Proctor and Delgado (ref. 2) are shown that brush and finger seal power losses are similar. In their work they used an approximate solution by Schlichting (ref. 3) to account for windage due to high pressure on the test disk and balance piston that is not accounted for in the baseline tare data, since no test seal is used during the tare tests. They also estimated the additional power loss due to pressure loading on the test end bearing. The resultant approximation of the true finger seal power loss was one quarter of that originally calculated by simply measuring torque with and without a seal, taking the difference and multiplying it by speed. In this paper, the approximation of true seal power loss has been further refined and is based on empirical equations.

This paper presents additional leakage and power loss data from annular and labyrinth seal performance tests conducted in the NASA turbine seal rig. Comparisons are made to previously measured brush and finger seal data as well as data found in the literature. Literature relevant to windage loss and seal power loss is reviewed, followed by a description of the experiment and test procedures, the results and discussion.

\section{A. Literature Review}

A number of relevant references are summarized below that pertain to disk windage. Early experimental work in 1944 by Theodorsen and Regier (ref. 4) on the drag of revolving free disks substantiated drag formulas based on skin friction theories by von Karman and Prandtl. In 1960 Daily and Nece performed drag experiments on rotating disks enclosed in a housing with variable axial spacing between the housing wall and the disk surface (ref. 5). Results from their combined analytical and experimental work show the existence of four possible flow regimes between the disk and casing for a given $s / a$ ratio and Reynolds number. The $s / a$ ratio is the ratio of the disk radius to axial spacing, where the axial spacing is the distance between the disk and housing. Their work either verified or determined new empirical relationships for torque coefficients for the four flow regimes. They extended this work by showing that surface roughness on the disk increases the torque coefficient but only in the turbulent flow regime (ref. 6). Surface roughness was found to have no effect with flow in the laminar regime. In 1986 experimental and analytical work by Zimmerman et al. show the existence of friction losses for rotating disks with protruding or "staged" bolts (ref. 7). These friction losses were further divided into form drag, boundary layer losses, and pumping losses. The theoretical predictions were found to compare well with experiment for conditions with and without throughflow.

Initial work on the windage effect of rim seals in jet engines was reported by Haaser et al. in 1987 (ref. 8). The wheel space cavity of a jet engine was modeled accounting for inlet and exit flows and rotor and stator drag using conservation of angular momentum. The model was found to be in good agreement with full scale engine and test rig data. The s/a ratio given by Daily and Nece was accounted for as well as the effect of bolt drag. A double overlap seal design was recommended over the single overlap design for future turbine designs. In 1989 McGreehan and Ko carried out experimental work on the power dissipation of smooth and honeycomb labyrinth seals (ref. 9). One of their major findings was that the windage heating was generated mostly in the first 2 tooth pockets of a 5-knife labyrinth seal. Also of significance was the observation that labyrinth seal windage decreases with increasing inlet swirl velocity ratio. Work by Demko and others found the existence of a secondary recirculation zone inside the labyrinth seal cavity at high shaft speeds (ref. 10). In 1996 Millward and Edwards performed experimental and analytical work on labyrinth seals and found that seal power dissipation increases with increasing mass flow rate (ref. 1). Their work was also in agreement with the windage model of McGreehan and Ko. Finally, initial 
experimental and analytical work on the thermal interactions between a brush seal and shaft was performed by Owen et al. (ref. 11). A simple power law relationship is given relating the mass flow rate and shaft surface temperature to the power dissipated by the brush seal/disk surface interaction.

\section{B. Experiment}

\section{Turbine Seal Test Rig}

In the NASA High Temperature, High Speed Turbine Seal Test Rig, (fig. 1), the $215.9 \mathrm{~mm}$ diameter test disk is mounted on a shaft in an overhung configuration. The test disk is made of Grainex Mar-M 247 and its outer diameter is coated with chromium carbide $(\mathrm{CrC})$ applied with a high-velocity oxygen-fuel (HVOF) thermal spray process. The shaft is supported by two oil-lubricated bearings. A balance piston controls the axial thrust load on the bearings due to pressure loads on the test disk. An air turbine drives the test rig. A torquemeter is located between the air turbine and the test rig and is connected to each by quill shafts. The test seal is clamped into the Grainex Mar-M 247 seal holder as shown in figure 2. A C-seal located at the interface of the seal holder and test seal prevents flow from bypassing the test seal at its outer diameter. The seal holder is heated to approximately match the thermal growth of the disk and to prevent a change in radial clearance that may damage the seal and/or disk. Heated, filtered air enters the bottom of the test rig and passes through an inlet plenum that directs the heated air axially toward the seal-disk interface. The hot air either leaks through the test seal to the seal exhaust line or exits the rig before the test seal through a controlled bypass line at the top of the rig. If seal leakage is low, the bypass line must be open to maintain sufficient flow through the test rig to keep the rig hot.

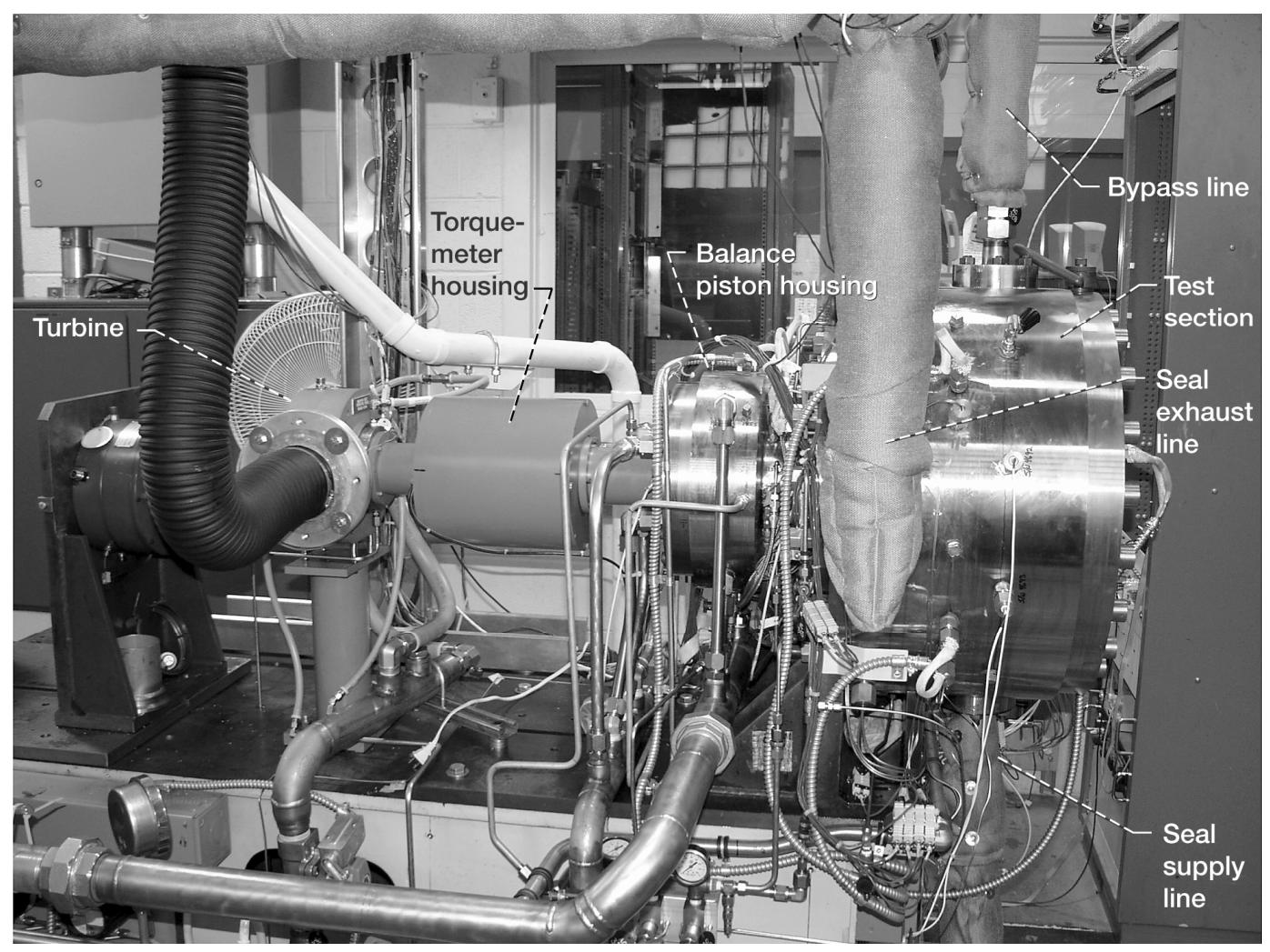

Figure 1.-High-temperature, high-speed turbine seal rig. 


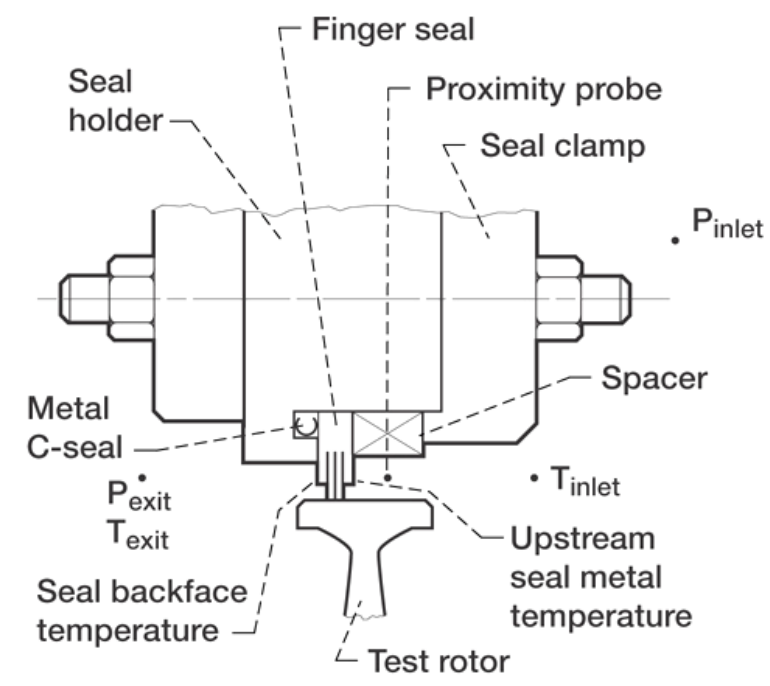

Figure 2.-Test seal configuration and location of research measurements.

\section{Instrumentation}

Seal inlet and exit temperatures and static pressures, seal upstream metal temperature (finger seal only), and seal backface temperatures are measured at the locations shown in figure 2. For each measurement there are 3 probes equally spaced around the circumference, except for the upstream seal metal temperature for which 2 thermocouples are located at the $90^{\circ}$ and $180^{\circ}$ positions $\left(0^{\circ}\right.$ is top-dead-center). Type-K thermocouples are used and all are $157 \mu \mathrm{m}$, Inconel sheath, closed ball except the seal exit temperatures, which are $3.2 \mathrm{~mm}$ diameter, and the seal metal and backface temperatures, which are open-ball.

High temperature capacitance proximity probes are mounted in the seal holder at four equally-spaced locations to view the test disk outer diameter. These probes are used to measure the change in clearance between the seal holder and the disk and to monitor the rotordynamic behavior of the test disk. The average inlet air temperature is used as the probe temperature when correcting the probe output. These proximity probes have an accuracy of $5 \mu \mathrm{m}$ at room temperature. Proximity probe data were only available for some of the finger seal tests due to instrumentation problems.

Pitot tube-type flow meters are used to measure the flow rates of the hot air supplied to the rig and the air exiting the rig through the bypass line. The seal leakage rate is the difference between these two flow measurements. The seal leakage rate is then used to calculate the flow factor, which is defined as:

$$
\phi=\frac{\dot{m} \sqrt{T_{\text {avg }}}}{P_{u} \times D_{\text {seal }}}, \mathrm{kg}-\sqrt{\mathrm{K}} / \mathrm{MPa}-\mathrm{m}-\mathrm{s}
$$

The flow factor can be used to compare the leakage performance of seals with different diameters and with different operating conditions. The accuracy of the measured flow factor is \pm 1.5 percent.

A phase shift torquemeter measures the total torque of the seal test rig and compensates for any relative motion between the torsion shaft and stator. The torquemeter is rated to $22 \mathrm{~N}-\mathrm{m}$, has a maximum operating speed of $5236 \mathrm{rad} / \mathrm{s}$, and an absolute accuracy of 0.13 percent or $0.028 \mathrm{~N}-\mathrm{m}$. The speed measurement from the torquemeter is accurate to $<0.04$ percent or $1.4 \mathrm{rad} / \mathrm{s}$ at the maximum speed tested.

3. Seal Power Loss

Seal power loss is calculated from measurements of torque, speed, inlet air temperature and pressure, and tare torque. Tare torque refers to the torque measured with no test seal installed. Tare torque was measured at inlet air temperatures of $297,605,700,811$, and $922 \mathrm{~K}$ and shaft speeds of 10, 16.2, 21.6, 27, and $32.6 \mathrm{krpm}$. Twodimensional curve fits of this data are used to determine the tare torque at intermediate inlet air temperature and speed conditions through interpolation. The tare data was measured at ambient pressure, because without a test seal installed there is no pressure differential across the test disk. 
When a test seal is installed the measured torque will include windage torque due to the higher pressure, and hence higher density, air on the high pressure sides of the seal test disk and the balance piston. This additional windage torque is calculated using formulations by Roelke (ref. 12) in which it is assumed that the test disk and balance piston are disks with parallel sides, that there is no through-flow, that the flow is turbulent, and that the clearance between the disks and their housings is large. The torque for friction loss on one side of a disk is shown in the following equation:

$$
M_{o}=C_{m, o} \rho \omega^{2} a^{5} /(4 g)
$$

The power loss due to friction on one side of a disk is simply the torque times the angular velocity.

The best empirical equation for torque coefficient for turbulent flow and large clearance was used and is given as:

$$
C_{m, o}=0.102(s / a)^{1 / 10} /\left(\mathrm{Re}^{1 / 5}\right)
$$

Inlet air temperature and pressure are used to determine the air viscosity and density for these calculations. The axial clearance, $s$, for the test disk and balance piston was approximated to be 0.0191 and $0.0127 \mathrm{~m}$, respectively. This methodology is different than the approximate solution by Schlichting (ref. 3) used previously by the authors in reference 2 primarily because the torque coefficient is based on empirical data.

In addition to the windage from the high pressure sides of the seal test disk and balance piston, when a pressure differential is applied to the seal the test end bearing experiences up to an additional axial load of $1334 \mathrm{~N}$, which will increase the bearing windage beyond what is included in the measured tare torque. This additional torque was estimated using a friction coefficient of 0.0015 in the equation below:

$$
T=f D_{1} W / 2 \quad \text { (from ref. 13) }
$$

Windage error in the tare torque due to changes in oil viscosity is expected to be small since the bearing temperature variation between the seal tests and the tare test was very small. Hence, the seal torque is the measured torque minus the sum of the tare torque, the additional windage torques on the test disk and balance piston due to pressure differential across the seal, and the bearing windage torque due to additional axial load on the test end bearing. The power loss presented is the seal torque times the angular velocity.

\section{Effective Clearance}

In calculating the effective clearance of a seal it is assumed that the flow is isentropic, compressible, choked flow through an annular clearance with an inner diameter $D_{\text {seal }}$. The effective clearance, $C_{\text {eff, }}$, is directly proportional to the flow factor as shown below:

$$
\mathrm{C}_{\text {eff }}=\mathrm{R}(0.8333)^{0.5} /\left(\pi(0.5283) \sqrt{\gamma \mathrm{Rg}_{\mathrm{c}}}\right) \phi
$$

Using the values for $\mathrm{R}$ and $\gamma$ for air as shown in the nomenclature, equation (5) reduces to

$$
C_{\text {eff }}=7.874938 \phi
$$

\section{Test Procedures}

Annular and 4-knife labyrinth seal performance data were taken to be compared to previous brush and finger seal data. Table 1 gives the material, seal inner diameter, radial clearance, axial length and other relevant information for each of these seals shown in figures 3 to 6 . 
TABLE 1.-DESIGN PARAMETERS FOR SEALS TESTED

\begin{tabular}{|l|c|c|c|c|l|}
\hline Seal type & Material & $\begin{array}{c}\text { Seal I.D. } \\
{[\mathrm{mm}]}\end{array}$ & $\begin{array}{c}\text { Radial clearance } \\
\text { at } 297 \mathrm{~K} \\
{[\mathrm{~mm}]}\end{array}$ & $\begin{array}{c}\text { Axial length } \\
{[\mathrm{mm}]}\end{array}$ & \multicolumn{1}{|c|}{ Other } \\
\hline Annular & Inco 625 & 216.5096 & 0.3048 & 11.2 & \\
\hline $\begin{array}{l}\text { 4-knife } \\
\text { labyrinth }\end{array}$ & Inco 625 & 216.5096 & 0.3048 & $\begin{array}{l}\text { Tooth height }=0.762 \mathrm{~mm} \\
\text { Pitch }=1.016 \mathrm{~mm} \\
\text { Tip width }=0.318 \mathrm{~mm} \\
\text { Tooth angle }=7.5^{\circ}\end{array}$ \\
\hline Brush & $\begin{array}{c}\text { Haynes 25 } \\
\text { bristles } \\
\text { Inco 625 } \\
\text { sideplates }\end{array}$ & 215.6968 & -0.0965 & $\begin{array}{l}\text { pristle lay angle }=50^{\circ} \\
\text { pack width }\end{array}$ & $\begin{array}{l}\text { Bristle dia. }=102 \mu \mathrm{m} \\
\text { Density }=68 \mathrm{wires} / \mathrm{mm} \\
\text { Fence height }=1.27 \mathrm{~mm}\end{array}$ \\
\hline Finger & $\begin{array}{c}\text { Haynes 25 } \\
\text { sheet per } \\
\text { AMS5537 }\end{array}$ & 215.5520 & -0.165 & $\begin{array}{l}\text { Similar to } \\
\text { brush seal }\end{array}$ & Pressure-balanced design \\
\hline
\end{tabular}

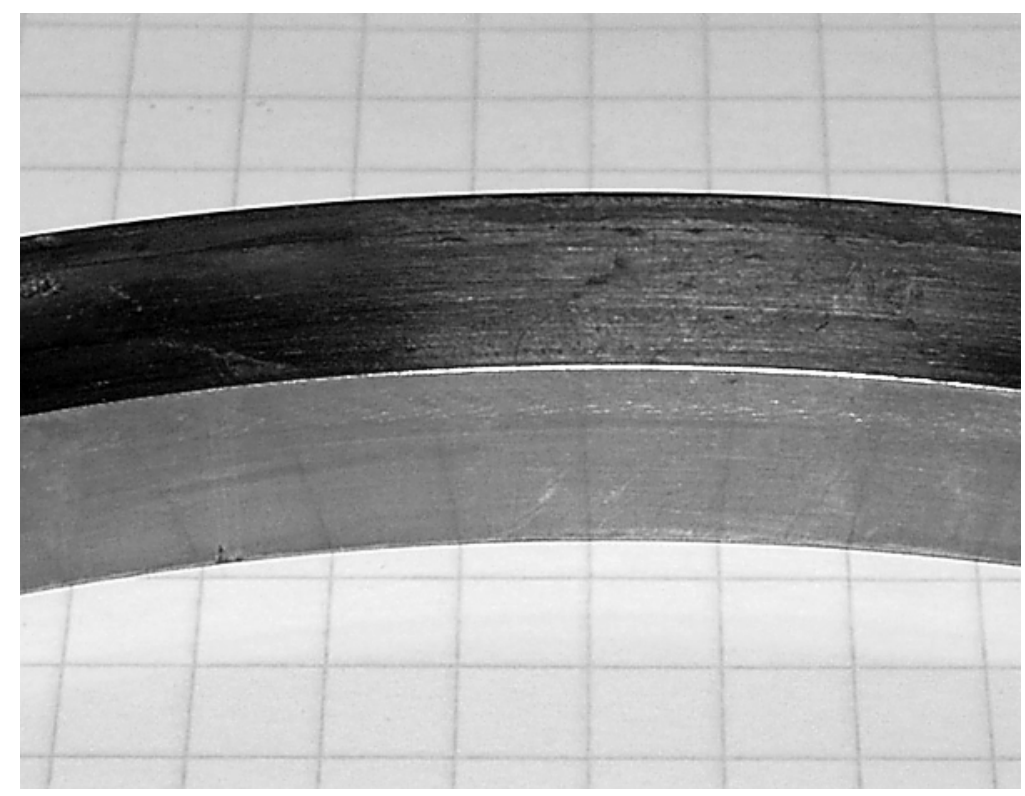

Figure 3.-Annular seal made of Inconel 625. Note, each grid square is $6.35 \mathrm{~mm}$.

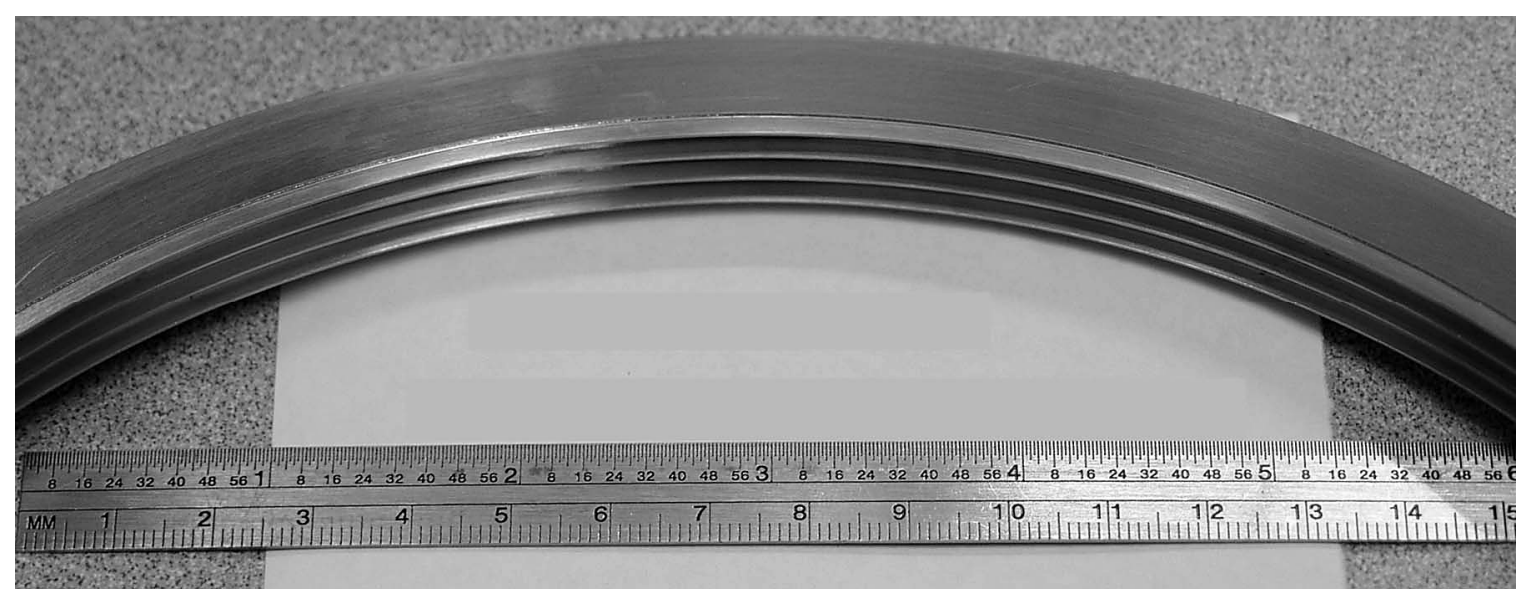

Figure 4.-Four-knife labyrinth seal made of Inconel 625. 


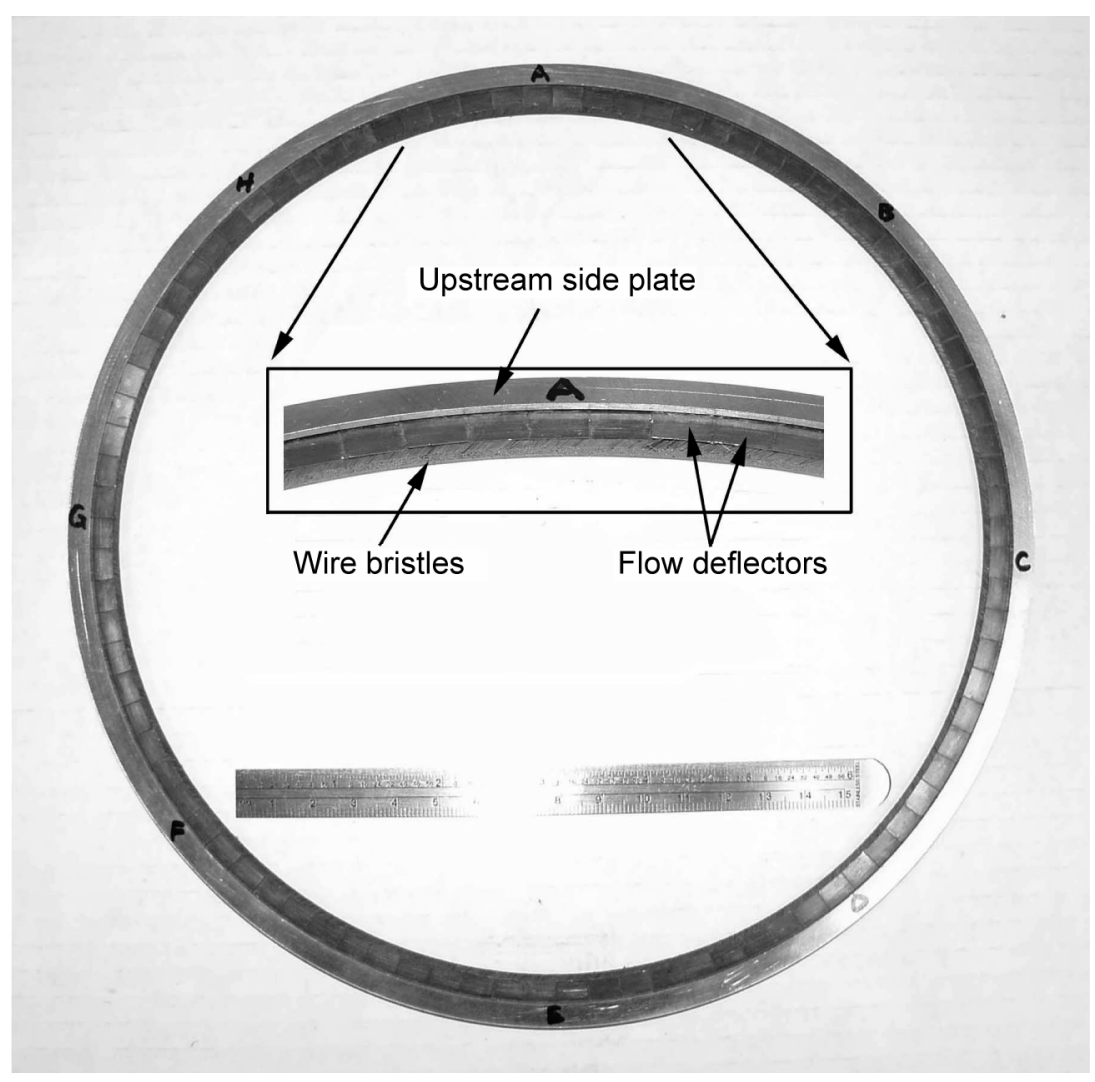

Figure 5.-Brush seal with flow deflector.
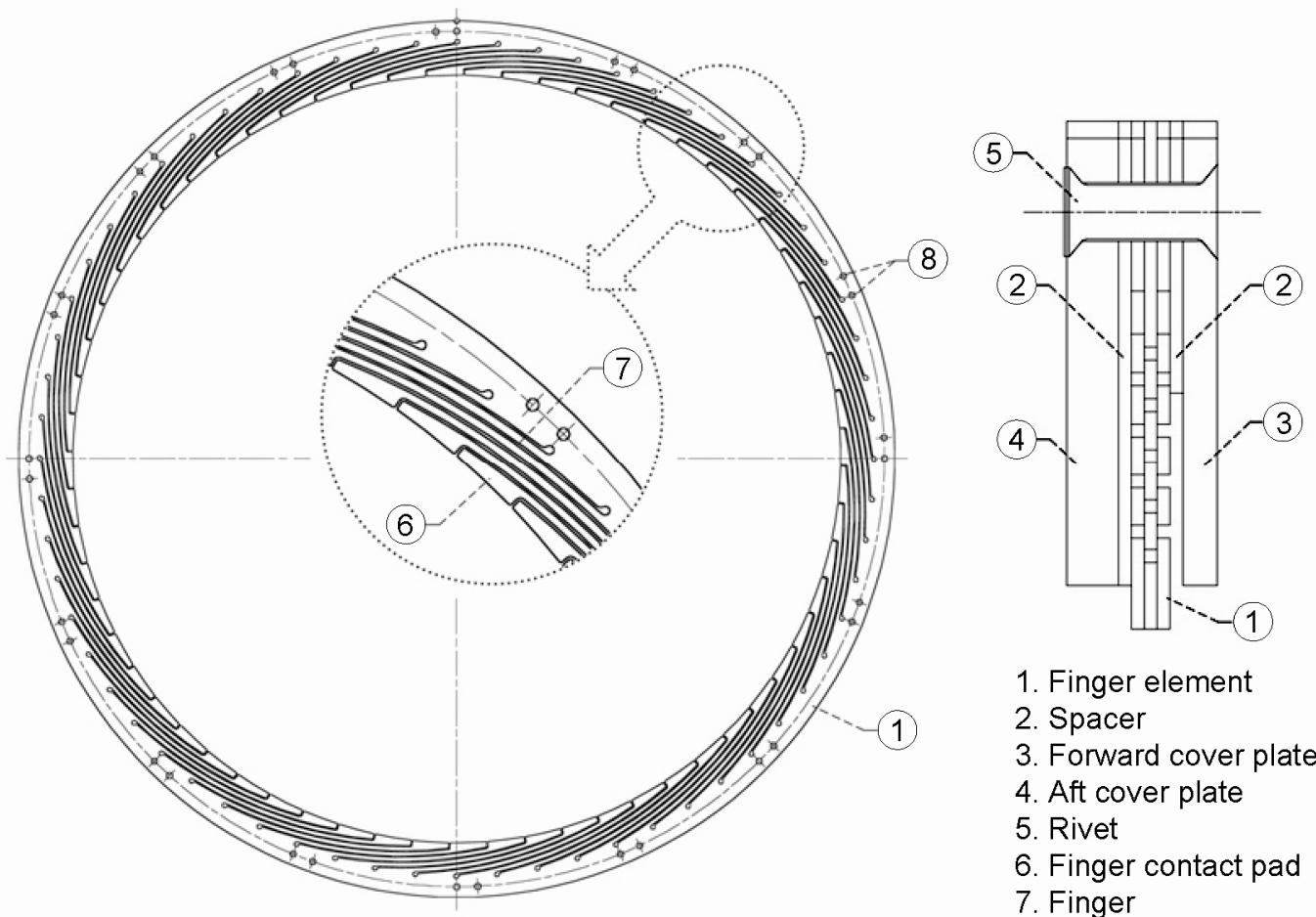

1. Finger element

2. Spacer

3. Forward cover plate

4. Aft cover plate

5. Rivet

6 . Finger contact pad

7. Finger

8. Indexing and rivet holes

Figure 6.-Finger seal design. 
Annular and labyrinth seal performance tests were conducted at 5 temperatures. At each temperature the pressure differential across the seal was held constant while stepping up and down in surface speed. At each temperature, pressure, and speed condition, seal torque and leakage were recorded. Annular and labyrinth seal test conditions are given in table 2 with brush and finger seal test conditions from previous tests.

TABLE 2.-TEST CONDITIONS FOR EACH SEAL

\begin{tabular}{|c|c|c|c|c|c|}
\hline Seal type & $297 \mathrm{~K}$ & $533 \mathrm{~K}$ & $700 \mathrm{~K}$ & $811 \mathrm{~K}$ & $922 \mathrm{~K}$ \\
\hline Annular & $\begin{array}{c}69,276,345 \mathrm{kPa} \\
\text { at } \\
0,113,183,274 \mathrm{~m} / \mathrm{s}\end{array}$ & $\begin{array}{c}69,276,345 \mathrm{kPa} \\
\text { at } \\
0,113,183,274 \mathrm{~m} / \mathrm{s}\end{array}$ & $\begin{array}{c}69,276 \mathrm{kPa} \\
\text { at } \\
0,113,183,274 \mathrm{~m} / \mathrm{s}\end{array}$ & $\begin{array}{c}69,138 \mathrm{kPa} \\
\text { at } \\
0,113,183,274 \mathrm{~m} / \mathrm{s}\end{array}$ & $\begin{array}{c}69,138 \mathrm{kPa} \\
\text { at } \\
0,113,183,274 \mathrm{~m} / \mathrm{s}\end{array}$ \\
\hline $\begin{array}{l}\text { 4-knife } \\
\text { labyrinth }\end{array}$ & $\begin{array}{c}69,276,345 \mathrm{kPa} \\
\text { at } \\
0,113,183,283 \mathrm{~m} / \mathrm{s}\end{array}$ & $\begin{array}{c}69,276,345 \mathrm{kPa} \\
\text { at } \\
0,113,183,283 \mathrm{~m} / \mathrm{s}\end{array}$ & $\begin{array}{c}69,276,345 \mathrm{kPa} \\
\text { at } \\
0,113,183,283 \mathrm{~m} / \mathrm{s}\end{array}$ & $\begin{array}{c}69,276,345 \mathrm{kPa} \\
\text { at } \\
0,113,183,283 \mathrm{~m} / \mathrm{s}\end{array}$ & $\begin{array}{c}69,276 \mathrm{kPa} \\
\text { at } \\
0,113,183,283 \mathrm{~m} / \mathrm{s}\end{array}$ \\
\hline Brush & $\begin{array}{c}69,276,517 \mathrm{kPa} \\
\text { at } \\
0,183,274,366 \mathrm{~m} / \mathrm{s}\end{array}$ & $\begin{array}{c}69,276,517 \mathrm{kPa} \\
\text { at } \\
0,183,274,366 \mathrm{~m} / \mathrm{s}\end{array}$ & $\begin{array}{c}69,276,517 \mathrm{kPa} \\
\text { at } \\
0,183,274,366 \mathrm{~m} / \mathrm{s}\end{array}$ & $\begin{array}{c}69,276,517 \mathrm{kPa} \\
\text { at } \\
0,183,274,366 \mathrm{~m} / \mathrm{s}\end{array}$ & $\begin{array}{c}69,276,517 \mathrm{kPa} \\
\text { at } \\
0,183,274,366 \mathrm{~m} / \mathrm{s}\end{array}$ \\
\hline Finger & N/A & N/A & $\begin{array}{c}69,276,517 \mathrm{kPa} \\
\text { at } \\
0,183,274,366 \mathrm{~m} / \mathrm{s}\end{array}$ & N/A & $\begin{array}{c}69,276,517 \mathrm{kPa} \\
\text { at } \\
0,183,274,366 \mathrm{~m} / \mathrm{s}\end{array}$ \\
\hline
\end{tabular}

\section{Results and Discussion}

\section{Seal Leakage}

Figure 7 shows annular, labyrinth, brush, and finger seal flow factor data versus surface speed at a temperature of $700 \mathrm{~K}$ and a pressure differential of $276 \mathrm{kPa}$. The flow factor decreases with increasing surface speed. This decrease in flow factor is due to centrifugal growth of the test disk which reduces the clearance between the test seal and disk. In general, at constant temperature, annular seal flow factor data are the largest in magnitude followed by those for labyrinth, brush, and finger seals. For example, at $700 \mathrm{~K}, 276 \mathrm{kPa}$, and $183 \mathrm{~m} / \mathrm{s}$ the annular seal flow factor is 8 times that of the finger seal and 2.5 times that of the brush seal. This is largely due to the fact that the annular and labyrinth seals have starting clearances $(0.305 \mathrm{~mm})$ while the brush and finger seals are installed with a slight interference fit. Moreover the brush seal bristle and finger seal laminates will bend radially inward due to pressure (i.e., pressure closing effect) which results in decreased flow rates through the seal/disk annulus.

Comparing figures 7, 8, and 9, the flow factor also rises with increasing temperature. Annular and labyrinth seal flow factors increase by approximately 50 percent when the air temperature is increased from 297 to $700 \mathrm{~K}$.

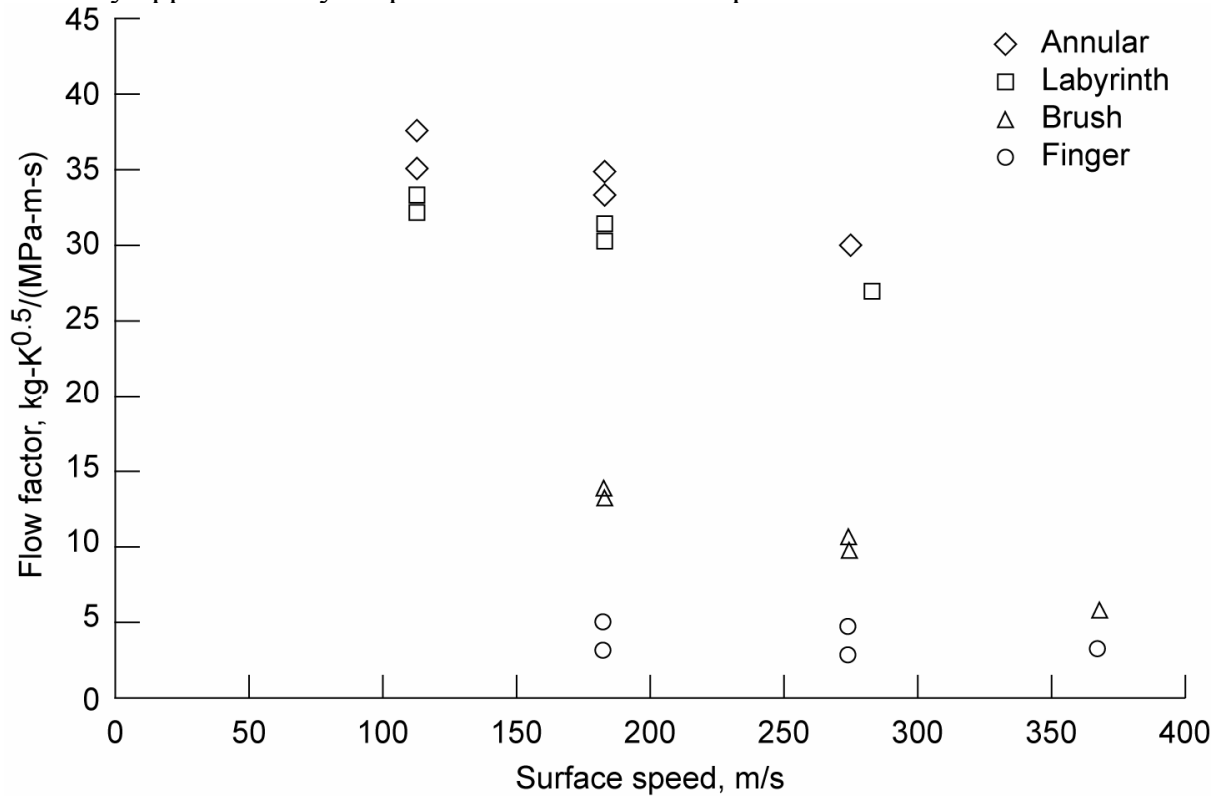

Figure 7.--Leakage flow factor for annular, 4-knife labyrinth, brush, and finger seals as a function of speed. Inlet air temperature $=700 \mathrm{~K}$; Seal pressure differential $=276 \mathrm{kPa}$. 


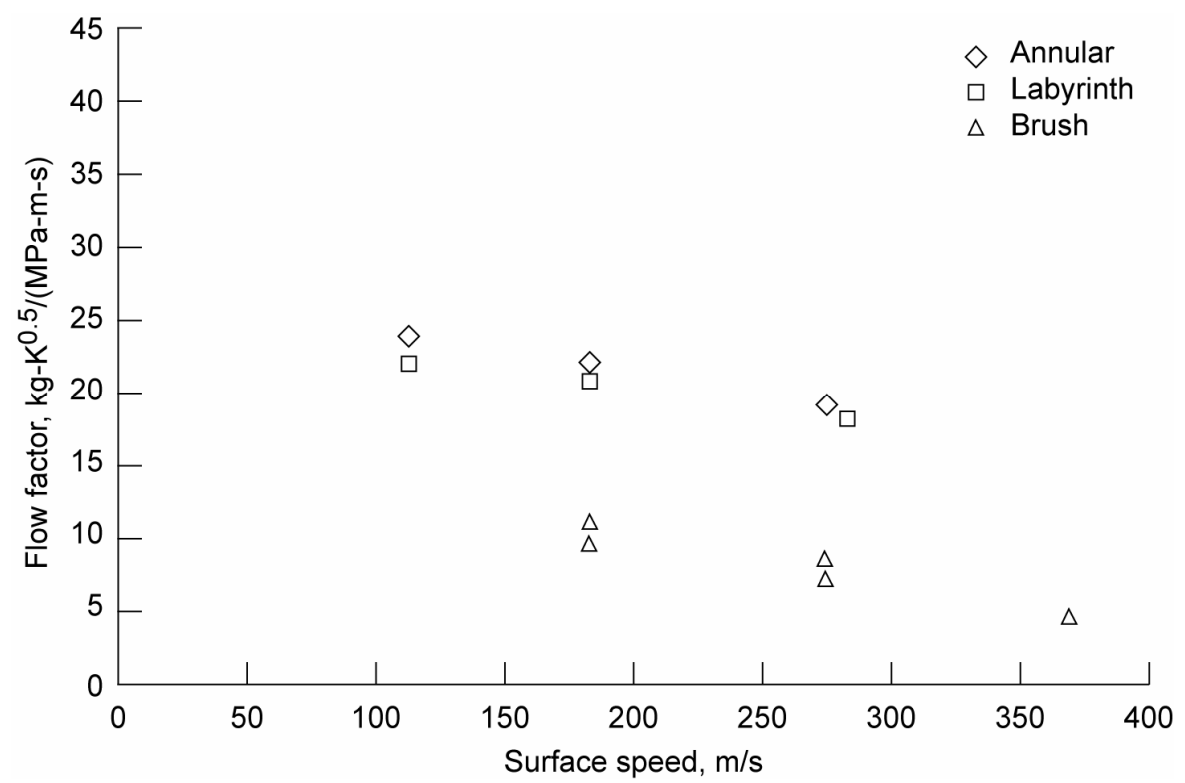

Figure 8.-Leakage flow factor for annular, 4-knife labyrinth and brush seals as a function of speed. Inlet air temperature $=297 \mathrm{~K}$; Seal pressure differential $=276 \mathrm{kPa}$.

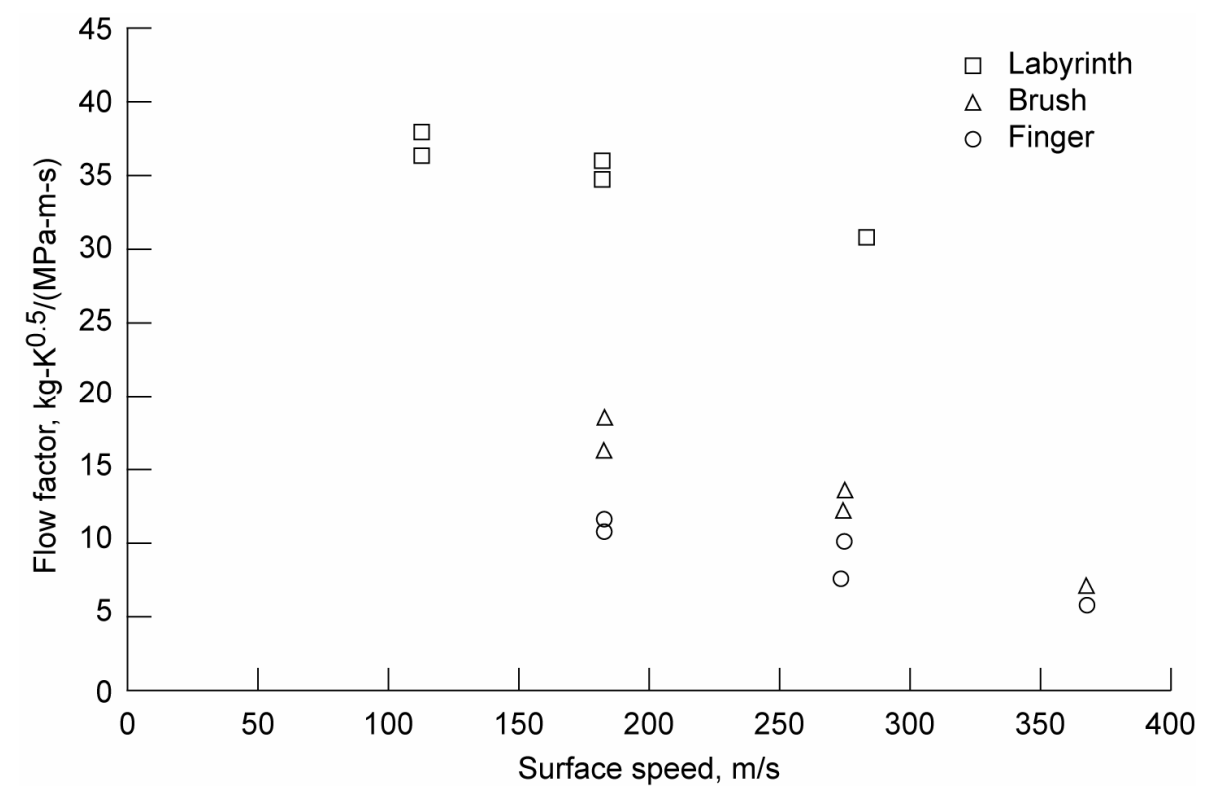

Figure 9.- - Leakage flow factor for 4-knife labyrinth, brush, and finger seals as a function of speed. Inlet air temperature $=922 \mathrm{~K}$; Seal pressure differential $=276 \mathrm{kPa}$.

Comparing the labyrinth data at 297 and $900 \mathrm{~K}$ the flow factor increase is approximately 70 percent. Brush seal flow factor increases by 24 to 30 percent from 297 to $700 \mathrm{~K}$, and by 67 percent from 297 to $922 \mathrm{~K}$. The finger seal flow factor data had the largest percentage increase. Comparing finger seal flow factor data from 700 to $922 \mathrm{~K}$, an increase of 174 percent is observed at $183 \mathrm{~m} / \mathrm{s}, 135$ percent at $274 \mathrm{~m} / \mathrm{s}$, and 82 percent at $366 \mathrm{~m} / \mathrm{s}$. Overall, the finger seal and brush seal flow factors are $1 / 3$ to $1 / 2$ the annular or labyrinth seal flow factors. This is because the annular and labyrinth seal radial clearances are nominally $0.305 \mathrm{~mm}$ while the brush and finger seals are installed with a slight interference fit. While thermal expansion coefficients for the Haynes 25 brush seal and the Inco 625 labyrinth seal are similar, they are both greater than the Grainex Mar-M 247 disk thermal expansion coefficient. Thus both seals will grow radially outward from the disk at higher test temperatures resulting in larger seal clearances and higher flow rates. 


\section{Seal Power Loss}

Seal power loss was not strongly affected by inlet temperature. Plots of seal power loss versus surface speed are shown in figures 10,11 , and 12 at a constant pressure differential of $276 \mathrm{kPa}$ at temperatures of 297,700 , and $922 \mathrm{~K}$, respectively. For each seal, the seal power loss varied by \pm 5 percent at most with change in temperature. Annular and labyrinth seal power loss is consistently higher than brush or finger seal power loss at each of the temperatures tested. Brush seals have the lowest power loss with values 15 to 30 percent less than annular and labyrinth seal power loss. For all four seals tested, seal power loss values are within $1 \mathrm{~kW}$ of each other for a constant temperature, pressure differential, and surface speed.

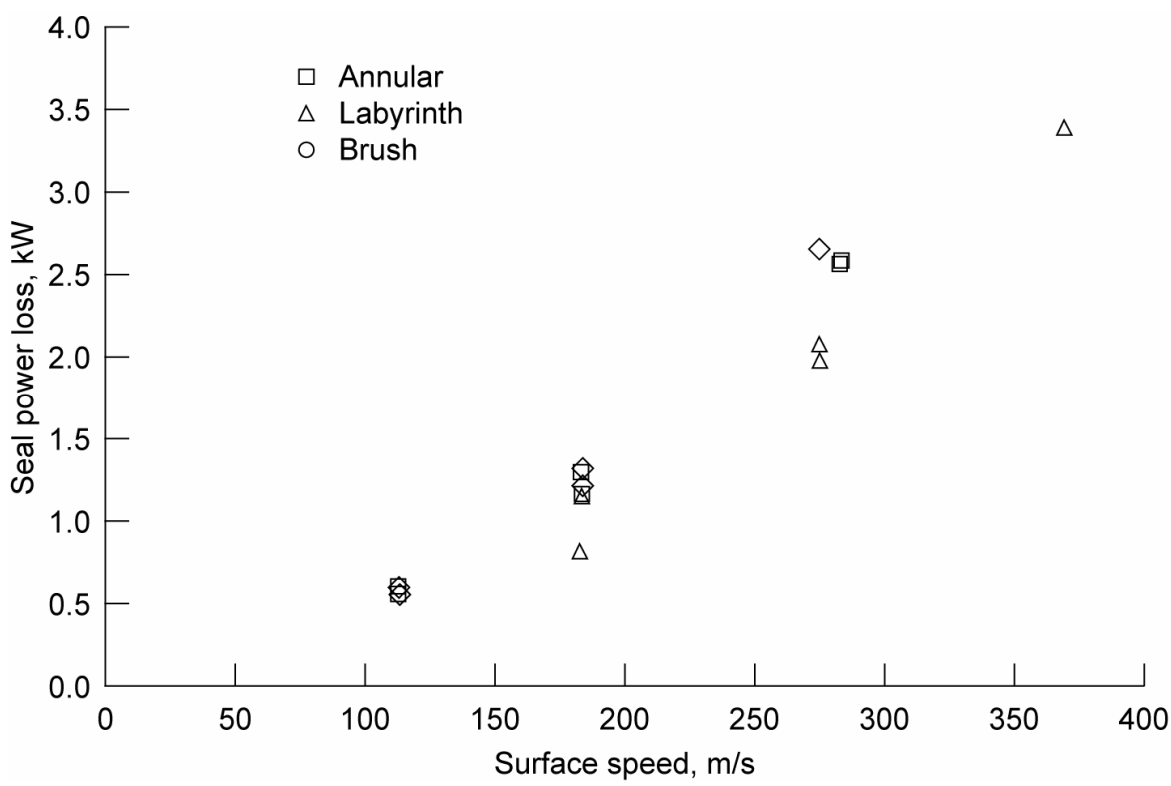

Figure 10.- Seal power loss for annular, 4-knife labyrinth and brush seals as a function of speed. Inlet air temperature $=297 \mathrm{~K}$; Seal pressure differential $=276 \mathrm{kPa}$.

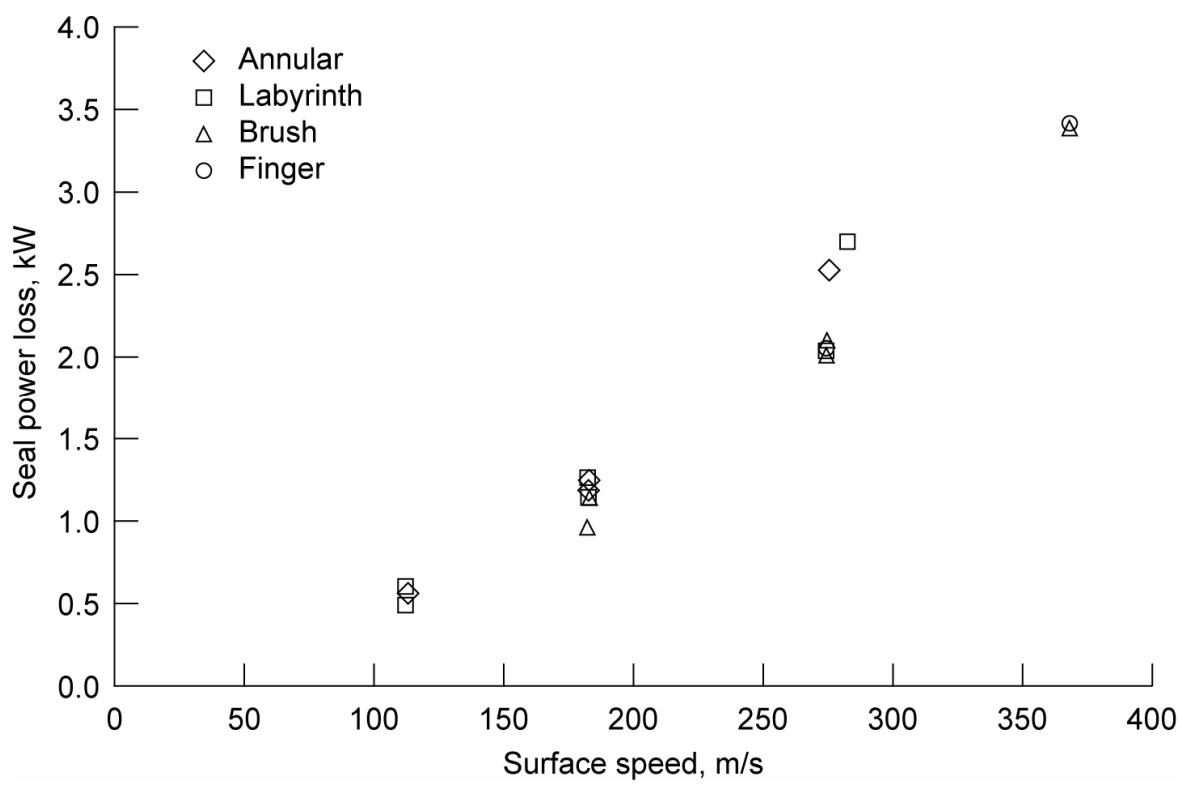

Figure 11.- Seal power loss for annular, 4-knife labyrinth, brush, and finger seals as a function of speed. Inlet air temperature $=700 \mathrm{~K}$; Seal pressure differential $=276 \mathrm{kPa}$. 


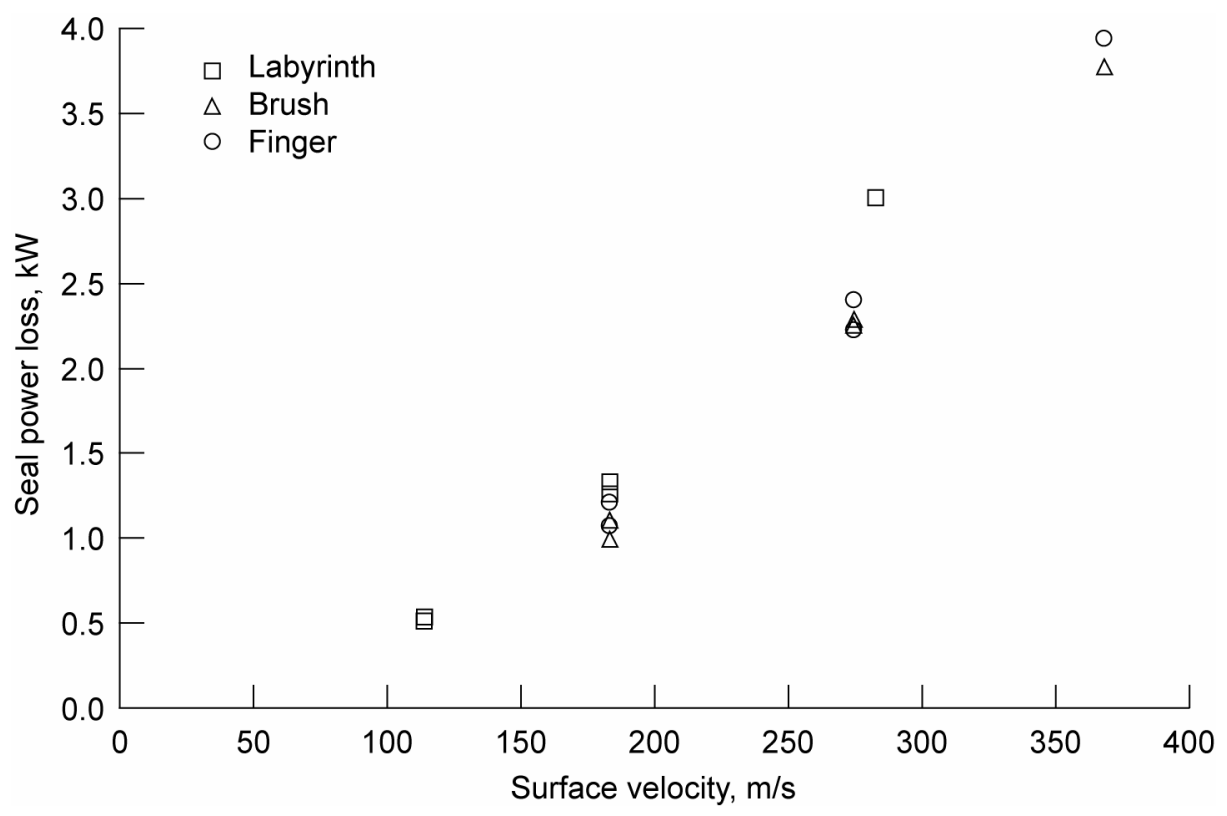

Figure 12.- Seal power loss for 4-knife labyrinth, brush, and finger seals as a function of speed. Inlet air temperature $=922 \mathrm{~K}$; Seal pressure differential $=276 \mathrm{kPa}$.

In general, data with respect to surface speed, pressure differential, and seal inlet mass flow rate are in agreement with findings by Millward and Edwards (ref. 1). As expected, seal power loss increases with increasing speed. Comparing figures 11 and 13, seal power loss increases with increasing seal pressure differential, also in agreement with data from Millward and Edwards. For example at $700 \mathrm{~K}, 68.9 \mathrm{kPa}$, and $183 \mathrm{~m} / \mathrm{s}$ the seal power loss for all seals tested was approximately 0.3 to $0.7 \mathrm{~kW}$. At $700 \mathrm{~K}, 276 \mathrm{kPa}$, and $183 \mathrm{~m} / \mathrm{s}$ the seal power loss was approximately 0.9 to $1.3 \mathrm{~kW}$. Finally, seal power loss is found to be strongly affected by flow factor or essentially mass flow rate as shown in figure 14. This also agrees with findings by Millward and Edwards. We have shown that effective clearance is proportional to flow factor in equation (6) and flow factor is proportional to seal mass leakage rate in equation (1). Therefore because seal power loss increases with seal leakage rate, power loss also increases as radial clearance increases. This also agrees with Millward and Edwards' findings.

Labyrinth seal power loss at $276 \mathrm{kPa}$ and $700 \mathrm{~K}$ compare reasonably well with data from McGreehan and Ko. At $200 \mathrm{~m} / \mathrm{s}$ the NASA labyrinth seal power loss data is approximately $1.5 \mathrm{~kW}$. Data from McGreehan and Ko, at a slightly lower temperature $(505 \mathrm{~K}$ ) at $200 \mathrm{~m} / \mathrm{s}$ is approximately $1.2 \mathrm{~kW}$ (ref. 9). Note that the 5 -knife labyrinth seal used by McGreehan and Ko has a $0.19 \mathrm{~mm}$ radial clearance at a diameter of $19.05 \mathrm{~cm}$ while the NASA 4-knife labyrinth seal has an installed radial clearance of $0.30 \mathrm{~mm}$ at a diameter of $21.65 \mathrm{~cm}$.

Labyrinth seal power losses from Millward and Edwards are slightly higher than NASA data. At ambient temperature, a seal pressure differential of $276 \mathrm{kPa}$, and a surface speed of $282 \mathrm{~m} / \mathrm{s}$ the seal power loss for the NASA test is approximately $2.6 \mathrm{~kW}$, (fig. 10). Extrapolated data from Millward and Edwards ranges from approximately 4.0 to $8.0 \mathrm{~kW}$. However, there are differences in both data sets. The NASA labyrinth seal is a 4-knife design compared to the 5-fin labyrinth seal of the Millward and Edwards test. Also the radial clearance for the NASA seal is $0.30 \mathrm{~mm}$ compared to $1.12 \mathrm{~mm}$ for Millward and Edwards. Finally the pressure ratio for the NASA labyrinth seal test is 3.5 compared to 1.5 for the Millward and Edwards test. Clearly, the effect of the number of seal fins or teeth, seal radial clearance, and seal pressure ratio on seal power loss are not negligible. The effect of axial thickness is unknown. Also note that the Millward and Edwards labyrinth seal axial width is twice that of the NASA seal. Finally, the NASA 4-knife labyrinth seal is adjacent to a rotating smooth surface while the Millward and Edwards 5-knife labyrinth rotates adjacent to a stator.

Brush seal power loss is higher than that of Millward and Edwards brush seal power loss data. NASA brush seal power loss was slightly less than $2 \mathrm{~kW}$ at ambient temperature, $276 \mathrm{kPa}$ and $264 \mathrm{~m} / \mathrm{s}$ compared to approximately $1 \mathrm{~kW}$ power loss reported by Millward and Edwards. Differences in the data sets include seal diameter, pressure ratio, and radial clearance. The NASA brush seal had an initial radial interference of $0.0965 \mathrm{~mm}$. Millward and Edwards' brush seal had zero clearance. Thus the initial interference in the NASA brush seal may have contributed 


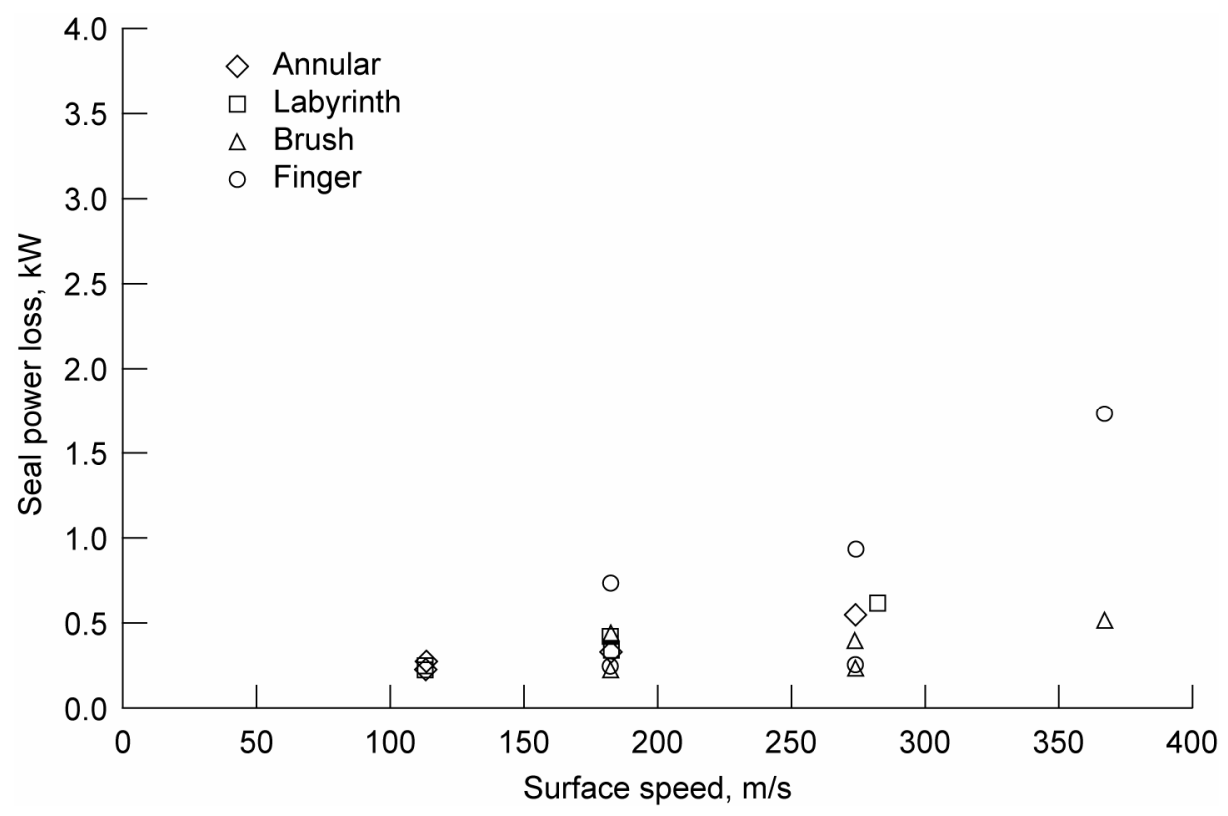

Figure 13.- Seal power loss for annular, 4-knife labyrinth, brush, and finger seals as a function of speed. Inlet air temperature $=700 \mathrm{~K}$; Seal pressure differential $=68.9 \mathrm{kPa}$.

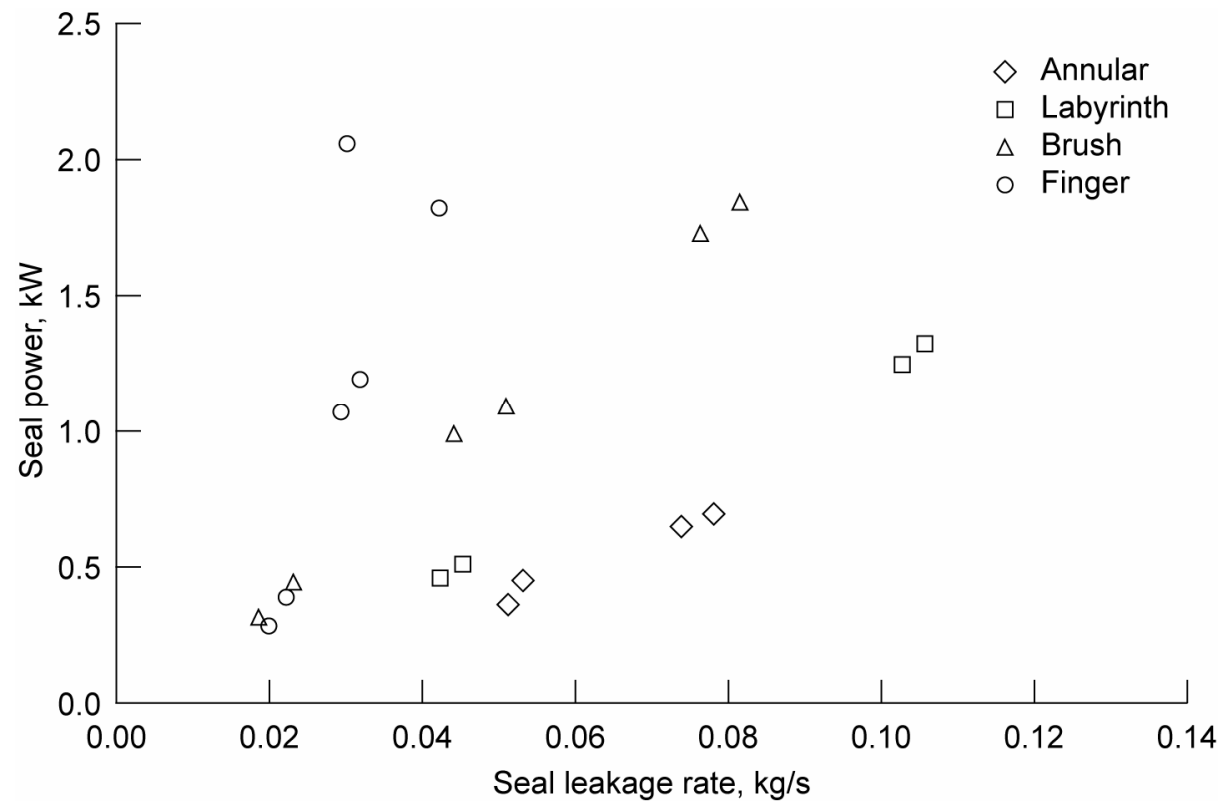

Figure 14.- Seal power loss for annular, 4-knife labyrinth, brush, and finger seals as a function of mass flow rate. Inlet air temperature $=922 \mathrm{~K}$; Surface speed $=183 \mathrm{~m} / \mathrm{s}$.

to the observed higher power loss. Also, the NASA brush seal had an upstream to downstream pressure ratio of 3.4 versus Millward and Edwards' brush seal pressure ratio of 1.3. Therefore the NASA brush seal would have a greater pressure closing force to load the bristles into the rotor and produce more seal power loss. The ratio of the NASA brush seal diameter of $215.9 \mathrm{~mm}$ to the Millward and Edwards' brush seal diameter of $388 \mathrm{~mm}$ is 0.53 . This explains to a large extent why the NASA brush seal had a lower flow rate, $0.03 \mathrm{~kg} / \mathrm{s}$, versus approximately $0.1 \mathrm{~kg} / \mathrm{s}$ in the Millward and Edwards' brush seal since the mass leakage rate is proportional to seal diameter.

Factors found to affect seal power loss include disk surface speed; seal pressure differential (and thus air density and viscosity), seal pressure closing forces, seal radial clearance, and mass flow rate. Intuitively, axial length of the 
seal would affect seal power loss as well. One would expect a shorter seal to have less power loss than a longer one. The data support this expectation since the brush and finger seals had lower power loss than the cylindrical and labyrinth seals and the axial lengths of the brush and finger seals were less than 40 percent of the length of the cylindrical and 4-knife labyrinth seals. However this is not a conclusive finding since other factors associated with the various seal types affect power loss. Testing different axial length seals of the same seal type would be needed.

Seal designers must account for windage and seal power loss to ensure that component lives, especially in the turbine section of the jet engine, are not shortened due to additional heat input nor engine power robbed by excess seal power loss. The purpose of these seal power loss experiments in the turbine seal test facility at NASA is to provide baseline data for current and future engine seals. Part of the experimental process has been to calibrate the power loss data such that only the power loss due to the seal is determined. Effects accounted for by the torquemeter include the pressure loading on the high pressure side of the test disk, including bolt protrusions. Approaches to improve the ability to predict and measure seal power loss and to reduce windage heating include CFD analyses and measuring pressures and temperatures internal to the seal to verify the model. Further testing using a design of experiment or Taguchi analysis approach could determine which operating or design parameters have the most effect on seal power loss.

Also, testing the effect of swirl or airflow direction relative to the direction of the spinning disk could be compared to results obtained by McGreehan and Ko where they found that preswirl in the direction of rotation reduces seal power loss (ref. 9).

\section{Conclusions}

Leakage and seal power loss test data for annular and 4-knife labyrinth seals were obtained at various temperatures $(297,533,700,811,922 \mathrm{~K})$, seal pressure differentials $(69,138,276,345 \mathrm{kPa})$, and surface speeds $(113,183,274 \mathrm{~m} / \mathrm{s})$ at NASA Glenn Research Center's High Temperature Turbine Seal Test Rig. The data were compared to previous brush and finger seal test results. The following conclusions are given for the seals tested:

- Seal leakage decreases with increasing surface speed due to reduced clearances from disk centrifugal growth.

- Annular and labyrinth seal leakage is 2 to 3 times that of brush and finger seals.

- Seal leakage rates increased with increasing temperature because of seal clearance growth due to different coefficients of thermal expansion between the seal and test disk.

- Seal power loss is not strongly affected by inlet temperature.

- Seal power loss increases with increasing surface speed, seal pressure differential, mass flow rate or flow factor, and radial clearance.

- The brush and finger seals had nearly the same power loss.

- Annular and labyrinth seal power losses were higher than those of finger or brush seals. The brush seal power loss was the lowest and was 15 to 30 percent lower than annular and labyrinth seal power loss.

Further analytical and experimental work is needed to understand the effect of seal axial length and preswirl on seal power loss. The findings in this paper along with future work will aid seal designers in minimizing the seal heat generation and subsequent efficiency losses in jet engine applications.

\section{References}

1. Millward, J.A., and M.F. Edwards. "Windage Heating of Air Passing Through Labyrinth Seals.” Journal of Turbomachinery vol. 118. (1996): 414-419.

2. Proctor, M.P., and Delgado, I.R., 2004, "Leakage and Power Loss Test Results for Competing Turbine Engine Seals," NASA/TM-2004-213049, ARL-TR-3157, ASME GT2004-53935.

3. Schlichting, H., 1979, Boundary Layer Theory, Seventh Edition, McGraw-Hill, Inc., New York, pp. 242-243.

4. Theodorsen, Theodore, and Arthur Regier. "Experiments on Drag of Revolving Disks, Cylinders, and Streamline Rods at High Speeds." NACA-TR-793 (1944): 367-384.

5. Daily, J.W., and R.E. Nece. "Chamber Dimension Effects on Induced Flow and Frictional Resistance of Enclosed Rotating Disks.” Journal of Basic Engineering. (March 1960): 217-232.

6. Nece, R.E., and J.W. Daily. "Roughness Effects on Frictional Resistance of Enclosed Rotating Disks." Journal of Basic Engineering. (Sept. 1960): 553-560.

7. Zimmerman, H. et al. "Friction Losses and Flow Distribution for Rotating Disks with Shielded and Protruding Bolts." Journal of Engineering for Gas Turbines and Power. vol. 108 (July 1986): 547-552. 
8. Haaser, Fred, et al. "Windage Rise and Flowpath Gas Ingestion in Turbine Rim Cavities." ASME Paper 87GT-164. (May 1987): 1-10.

9. McGreehan, W.F., and S.H. Ko. "Power Dissipation in Smooth and Honeycomb Labyrinth Seals." ASME Paper 89-GT-220. (June 1989): 1-11.

10. Demko, J.A., et al. "Effect of Shaft Rotation on the Incompressible Flow in a Labyrinth Seal." Journal of Propulsion and Power. V6.2 (1990): 171-176.

11. Owen, Andrew K., et al. "An Experimental and Theoretical Study of Brush Seal and Shaft Thermal Interaction." Proc. of the ASME Turbo Expo 2003 V5B (2003): 977-984.

12. Roelke, Richard J., "Miscellaneous Losses," Turbine Design and Application, Vol. 2, edited by Glassman, Arthur J., 1973, NASA SP-290, pp. 131-137.

13. Townsend, D.P., Editor in Chief, 1991, Dudley’s Gear Handbook, 2nd edition, McGraw-Hill, Inc., New York, pp. 12.17-12.24. 


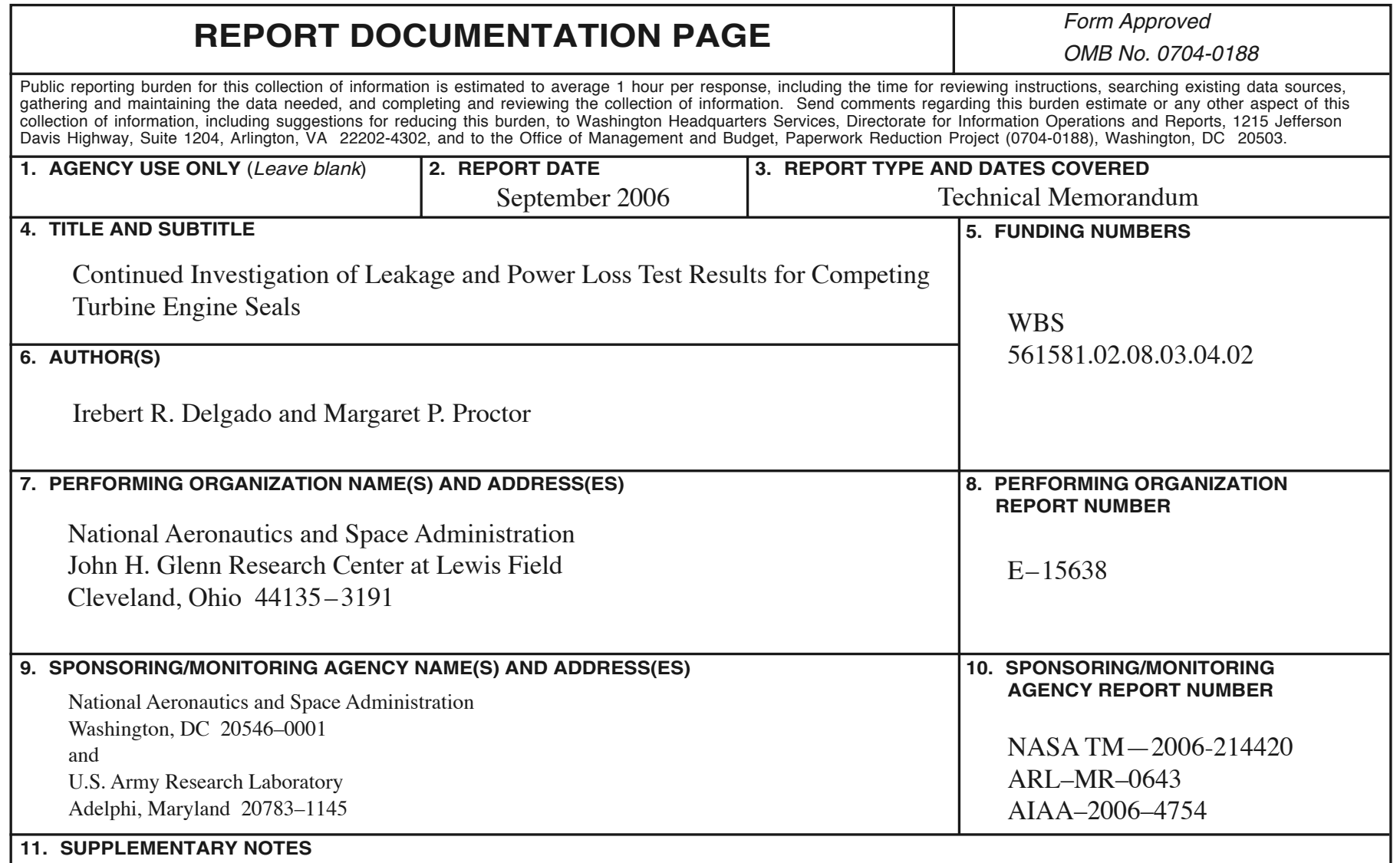

Prepared for the 42nd Joint Propulsion Conference and Exhibit cosponsored by the AIAA, ASME, SAE, and ASEE, Sacramento, California, July 9-12, 2006. Irebert R. Delgado, U.S. Army Research Laboratory, NASA Glenn Research Center; and Margaret P. Proctor, NASA Glenn Research Center. Responsible person, Irebert R. Delgado, organization code Z, 216-433-3935.

\begin{tabular}{|l|l|}
\hline 12a. DISTRIBUTION/AVAILABILITY STATEMENT & 12b. DISTRIBUTION CODE
\end{tabular}

Unclassified - Unlimited

Subject Category: 37

Available electronically at http://gltrs.grc.nasa.gov

This publication is available from the NASA Center for AeroSpace Information, 301-621-0390.

13. ABSTRACT (Maximum 200 words)

Secondary seal leakage in jet engine applications results in power losses to the engine cycle. Likewise, seal power loss in jet engines not only result in efficiency loss but also increase the heat input into the engine resulting in reduced component lives. Experimental work on labyrinth and annular seals was performed at NASA Glenn Research Center to quantify seal leakage and power loss at various temperatures, seal pressure differentials, and surface speeds. Data from annular and labyrinth seals are compared with previous brush and finger seal test results. Data are also compared to literature. Annular and labyrinth seal leakage rates are 2 to 3 times greater than brush and finger seal rates. Seal leakage decreases with increasing speed but increases with increasing test temperature due to thermal expansion mismatch. Also seal power loss increases with surface speed, seal pressure differential, mass flow rate, and radial clearance. Annular and labyrinth seal power losses were higher than those of brush or finger seal data. The brush seal power loss was 15 to 30 percent lower than annular and labyrinth seal power loss.

14. SUBJECT TERMS

Seal; Leakage; Power loss; Gas turbine; Engine seal

\begin{tabular}{|c|c|c|}
\hline $\begin{array}{c}\text { 17. SECURITY CLASSIFICATION } \\
\text { OF REPORT } \\
\text { Unclassified }\end{array}$ & $\begin{array}{c}\text { 18. SECURITY CLASSIFICATION } \\
\text { OF THIS PAGE } \\
\text { Unclassified }\end{array}$ & $\begin{array}{c}\text { 19. SECURITY CLASSIFICATION } \\
\text { OF ABSTRACT } \\
\text { Unclassified }\end{array}$ \\
\hline
\end{tabular}

NSN 7540-01-280-5500

Standard Form 298 (Rev. 2-89)

Prescribed by ANSI Std. Z39-18 298-102 

